\title{
Less Group Cohesion in Family Relationships of Female Street Prostitutes in Sri Lanka
}

\author{
Wasantha Subasinghe (PhD; Wuhan PRC), Professor, Department of Sociology, University of
}

Kelaniya, Sri Lanka.

wasanthasubasinghe@kln.ac.lk

Chithramala Dissanayake (MD: BHU India), Senior Lecturer, Department of Cikitsa, University of

Kelaniya, Sri Lanka.

chithramalad@kln.ac.lk

DOI: 10.29322/IJSRP.11.06.2021.p11419

http://dx.doi.org/10.29322/IJSRP.11.06.2021.p11419

\begin{abstract}
This paper discusses about the family background and socialization barriers of female commercial sex workers. There has been an increase in the number of street prostitutes over the past twenty years. The worst consequence is a loss of social respect and protection for women. A survey of 15 semi-structured interviews was conducted with respondents; obtained from the targeted sampling system for non-random sampling. There is a new trend with drug using and prostitution as well as low education level and prostitution. They sell, distribute, possess and use drugs. $33 \%$ of street prostitutes is not involved in drug trafficking. 67\% of street prostitutes use drugs. 35\% of street prostitutes are involved in drug trafficking. All street prostitutes have only gone to school until the grade ten. 13\% of them has never been to school in their lives. 66\% of street prostitutes are Sinhalese and 34\% are Tamils, no any Muslims. The childhood experiences of women in these street prostitutes are largely the same. When they were little, they received very little parental protection. As such, they were subjected to various forms of abuse. The main abuse was sexual abuse. All of these women had their first sexual intercourse between the ages of 12 and 14. The central and dominant social factor influencing women's prostitution was not having strong family ties and family protection. The child had not received the proper care from the group she had lived in when she was a child. Even after marriage, she does not receive proper care and support from her group. Some women ended their first marriage at the age of 18. She has to fulfill the needs of her life in her own strength. Therefore, women can achieve proper social status by developing group social cohesion.
\end{abstract}

Keywords: female sex worker, education level, family relationship, group social cohesion

Introduction

The Commercial sex industry has long history in worldwide even with different kinds of obstacles and challenges. Historically, kings, aristocracy, scholars and the common people had been employed in prostitution [1]. There is a legend saying that the king should be cautious about two people when governing the country; these two are the royal clown and the city beautician or a prostitute. However this commercialization of sex works is identified as prostitution. Although it was originated in the female sex trade, today it is listed in several categories as men, child and transgender prostitution. Prostitution is the practice, business, or occupation of engaging in sexual 
activity with someone in exchange for payment. There are "an estimated 42 million prostitutes around the world. There are fully legalized, limited legal and illegal countries for prostitution. Australia, Malaysia, Canada and France are some of limited legal countries for commercial sex works and Prostitution is legal and regulated in New Zealand, Denmark, Finland, Germany, Italy and India with more than 35 countries. Prostitution is illegal in countries such as Afghanistan, Iran, Iraq, South Korea, and North Korea etc". [2]. Prostitution is illegal and regulated by the Vagrants Ordinance, the Brothel Ordinance and the House of Detention Ordinance, which have existed since British colonial rule in Sri Lanka.

The Oxford Dictionary of Sociology defines a prostitute as "the provision of sexual favors for financially reward has probably been institutionalized in the form of prostitution in every society that has had a coinage. It has nearly always involved the prostitution of women to men, though male prostitution, especially to male clients, is not uncommon" [3].

Prostitution is a global phenomenon that is gendered: the majority of prostitutes are women, and the clients, men. When considering female prostitution, the categorization is different with place, price and its impact to the community. "The most consequential division in this stratification model is that between street and indoor prostitution. There are call girls, escorts, brothel workers, bar or casino workers and street walker [4]. Prostitution in Sri Lanka is estimated to involve 35,000 women by 2018 and it was estimated a total of 14,132 female sex workers in 2013 [5]. Operating from streets, brothels, massage parlours, lodges or hotels. Significant amount of them are street prostitutes and basically located in Colombo area. According to statistics 'there were 4100 female street sex workers in island wide and more than 3500 worked in Colombo' [6]. Prostitution as an industry; it has sex workers, pimps or brokers, managers, brothel owners and clients.

The concepts discussed in looking at the global spread of prostitution are various themes as labour exploitation, sexual rights, heterosexual matrix, masculine and feminine prostitution and so on. There are some of the concepts that need to be discussed when talking about the female prostitution in Sri Lanka. The concept of marriage, virginity, taboos and incest, religious beliefs and legal matters. There are four primary drives as food, water, sexual and rest drive for all animals. Human being fulfills these basic needs with obeying to social norms. Modern man believes in science and technology and acts according to law and custom. Humans do not share the same ideas about sex and try different ways to satisfy their sexual urges. The most common of these is giving in to the opposite sex. It happens through marriage. But in addition to that, homosexuality, masturbation, pornography, telephone sex, and online entertainments are also among them.

Sri Lankan society is subjected to special customs and beliefs regarding sexuality. Traditional Sri Lanka had polygamy; polyandry as well as polygyny $[7,8]$. There was a virginity test in traditional society as well as in modern society $[9,10]$. It is also believed that pious women became deities by having sex only for their husbands. Goddess Pathtini and Kali concept are examples for that [11]. Buddhist practices refuse sexual misconduct. Traditional Sinhala society was built on Buddhist cultures $[12,13]$.

A theoretical analysis of prostitution should be done when examining the factors that are important in a sociological explanation. A functional analysis of it can be done. Prostitution can also be 
described as conflicting. Prostitution is functional for several parties in society. It provides source of income by selling sex. It provides a sexual alternative for men who need a sexual partner for fulfill his sexual needs. It solve family sexual problems who have disable or unhealthy wives. It help to maintain less divorce rate [14]. There is a huge discrimination in employment basis on the sex [15]. On the other hand female prostitution make many negative consequences related to the family relationships, social status and self-esteem. When it comes to the social groups in which street prostitution is prevalent, it is possible to identify people who are socially marginalized. They are mostly vulnerable. On the other; hand the war left people helpless and displaced [16]. Selling sex is a deviant behavior in Sri Lankan context. Sex workers are getting stigmatized among others.

\section{Research Problem}

What about the family relationships of street prostitutes?

Research Aim

Understanding the Family Relationships of Street Prostitutes

Methodology

The ontological approach of this research is objectivism and epistemological approach is positivism. The research type is descriptive and quantitative. Survey method was used. Semistructured interviews were conducted with fifteen women formerly engaged in prostitution. Non probability purposive sampling theory was used to obtain the sample.

\section{Findings and Discussion}

Age: The women were met on the street in Fort, Bambalapitiya and Maradana mainly in Central Colombo. Special attention was paid to find out the contribution of the women around the family in which she lived to becoming street prostitutes. Everyone in the sample were met in the Colombo suburbs. All women were under 55 years of age. The oldest woman was 52 years old. One woman does not know her age and $53 \%$ are between the ages of 20-30. Also, 33\% were in the 40-50 age group. The appearance of many of these people looks messy and dirty. It looked older and about $26 \%$ said they maintained their beauty a bit. The 52-year-old woman had only a few teeth in her mouth and had fallen out. They said they had no idea of a nutritious balanced diet and would only get a meal to quench their hunger. There is no special addition of vegetables and fruits to the diet. Also do not take extra vitamins or other beverages. They live in low-income houses, slums and rented houses and do not have cultivable gardens. They do not have the culture to grow the vegetables or fruits they want. They buy everything they need for their daily lives. But the situation is different in the semi-urban and rural areas of Sri Lanka.

Civil Status: $100 \%$ of the sample were married women. All of them got married at the age of 18 . $27 \%$ of them are married by the age of 14 . Also, $53 \%$ are married by the age of 16 . Of these, $13 \%$ had no children and the remaining $87 \%$ had children. Of these, $27 \%$ had more than two children and $53 \%$ had more than four children. $55 \%$ of the total group has left their first marriage. $40 \%$ of them lives with another man, though not legally. About $20 \%$ of them are married to three people 
and all of them have children. $70 \%$ of these women lives with their mothers and the children are taken care of by those grandmothers. $7 \%$ of the children of these women live in orphanages run by NGOs. A significant number of these women 'children have also dropped out of school. It exceeds $70 \%$ of the total.

Ethnicity: $66 \%$ of street prostitutes are Sinhalese and 34\% are Tamils, no any Muslims. There were no other nationalities represented. Sinhalese come from Colombo, Gampaha, Anuradhapura, Kurunegala and Negombo so on. Tamil women come from estate sector such as Welimada and Nuwara Eliya, as well as Mannar and Batticaloa side even.

Education Level: The level of education of street prostitutes is considerable. All street prostitutes have only gone to school until the grade ten. $13 \%$ of them has never been to school in their lives. The government has provided free education to all people and has made primary compulsory, but about $27 \%$ of this group has only gone to school up to grade four. Those who studied up to eight years said that 'school work was not done successfully. Our parents had no knowledge to look after us. Our parents had not well learned. We didn't want to learn even'.

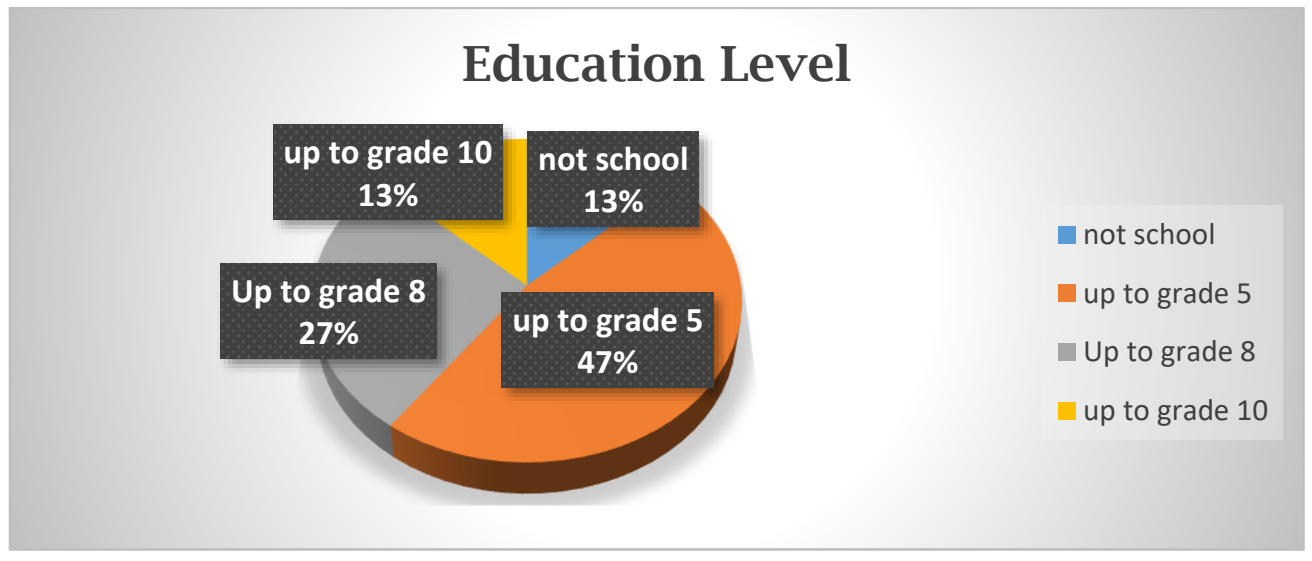

Source: Field data, 2019

Drug Use: There is a new trend of street prostitutes with drugs. They sell, distribute, possess and use drugs. $33 \%$ of street prostitutes is not involved in drug trafficking. $67 \%$ of street prostitutes use drugs. $35 \%$ of street prostitutes are involved in drug trafficking. The connection between drugs and street prostitution is a new co-relation. Not all street prostitutes use or sell drugs. But a significant number are addicted to drugs. But there was no such relationship about two decades ago. The street prostitute did this job to satisfy her daily need in earlier. Also to take care of their children. Now the situation is completely different. A woman in her fifties said that she entered prostitution in 1981 and had sex with more than a thousand men, but spent all the money she earned from the job on drugs. They need at least three thousand rupees a day for drugs. She said that now there are less clients and they do not come to her because she steals money from clients. Many street prostitutes are looking for money to buy drugs for their husbands as well. This is not a situation that existed before in this professional relationship. Therefore, all street prostitutes who 
use drugs engage in prostitution only to earn money to buy drugs. On the other hand, non-drug users work for the benefit of their children as well as their parents.

Mental and Physical Diseases: These women are facing to physical and mental illness as a result of being involved in prostitution for a long time. Before mental illness, they begin to suffer from physical illnesses. Maintaining close contacts with clients leads to infected with communicable as well as non-communicable diseases including psychosomatic ailments. Among those diseases Gastrointestinal Tract Related Diseases, Cardiovascular System Related Diseases, Respiratory System Related Diseases, Genitourinary System Related Diseases, Nervous System Related Diseases, Integumentary System Related Diseases and Psychiatric issues are much common. Being an illegal industry in Sri Lanka, most of prostitutes are exclusively vulnerable in mental ailments with unpleasant childhood experience likely being raped and victimized in sexual violence which leads to Post-Traumatic Stress Disease (PTSD), similarly likely anxiety, depression, hostility, substance addictions, psychosomatic disturbances and stress related Alzimers' Dementia are much common. Considering the psychosomatic disturbances; stress related Gastro-esophageal reflux disease, pancreatitis, hepatic steatosis, lactic acidosis are much common with Sexually Transmitted Diseases (STD); Similarly, infections related to STD cause cardiovascular, respiratory, genitourinary, nervous system and integumentary system disorders. Additionally, sedentary life styles of them leads to most of non-communicable diseases such as hypertension, dyslipidemia, insomnia, thyroid impairments and diabetes mellitus etc. [17-19].

Income and Clients: Woman who started with unsuccessful men are then living with or with their new partners with their children. Children have come to the streets and started the sex trade based on livelihoods. At a very young age, they have earned more. A mother engages in prostitution with her daughter said that the daughter was very beautiful and would sleep with businessmen for a sum of Rs. 25,000 at a time. This woman provides her services to a limited number of clients. At the same time, she is in the business of selling drugs. But does not use drugs.

Meanwhile, some street prostitutes have sex for between Rs. 3000-5000 at a time. But older women do sex work even for Rs. 1000 at a time to get drugs. There are some permanent clients pay five thousand rupees at a time. They only come once or twice a month. Among them are retired persons, employees of the security forces and manual workers. They also said that some persons are very kind and that they are often asked to quit their jobs and marry them. But they pointed out that, 'this is our job and our family members live on the money we earn'. Also, some people make money from this job to buy drugs for themselves and their husbands. But they specifically mentioned that no one having sex with school children. Those who engage in the sex trade to feed their children and parents, do it even without a fixed price. But they say that no matter how much they treat their family, they cannot receive love from them. The money they get from this job is only enough for their daily needs. They have no idea how to save. None of those families have the habit of saving. The life of drug addicts are tragic. Street prostitutes are also involved in temporary cleaning of private institutions and the city council.

They said they had sex with their client in a small rented room, in a three-wheeler, in a public restroom, inside drains, inside a lorry, on construction sites, old houses that have been demolished or even at a bus stop. When consider on their health care, but no matter how much they ask their 
clients, these prostitutes do not have sex without using condoms. These prostitutes have received knowledge and motivation from their professional friends. Also, the family planning worker had informed. Some women uses condoms about 50-60 a month. There are also people with mental disorders among clients. Some of them have voyeurisms, sadism, exhibitionisms and some are with masochisms. They pay for them without engaging sex.

Family Bond: It is especially important to look at the family environment of street prostitutes. All street prostitutes have the same experience with their family relationships. The mothers and fathers of all these women have not learned beyond primary education. Most families were divorced, separated from the father, the father had died, lived with the grandmother, or were female-headed families. Children in all families received affection from only one parent. Although the father is alive, they are fathers who are not economically or socially strong. Those fathers were not involved in family care and decision making. None of these parents of street prostitutes were not employed by the government. The parents worked as hired laborers, working in houses, working on tea estates, selling fish, and guarding estates and shops. They lived in very small houses or low-income houses. Some lived in slums and shanties in the city. More than 50\% of them still live in lowincome housing in the city. Some live on unauthorized land and many of those are government reservation lands.

The childhood experiences of women in these street prostitutes are largely the same. When they were little, they received very little parental protection. As such, they were subjected to various forms of abuse. The main abuse was sexual abuse. All of these women had their first sexual intercourse between the ages of 12 and 14. Among those who had sex were his mother's second husband, his sister's husband, a man in the house where she worked as a servant, or a neighbor she knew. They have become accustomed to having been sexually abused several times. They maintained that relationship until they reached the legal age of marriage. A person who is able to get married has started a married life with him. Or married with a fake age. Somehow the women who had children gave birth to their first child by the time they were 18 years old. Some women ended their first marriage at the age of 18.

These women did not have any friendships during their childhood or school days. They have no special friends. They have always lived a life without friends or acquaintances. At all times they only had people they met while in prostitution. They are only temporary service colleagues. They had no one to advise them to change their lives. They said they did not have friends to treat them with love. They claimed to live in isolation even though they lived among the crowd.

\section{Conclusion:}

Sri Lankan society still despises prostitution. Engaging in prostitution destroys a woman's social dignity. Also, all the family members of the woman who is engaged in prostitution are therefore depressed. Those families are also subjected to social stigma. They have more negative consequences than the functional value of prostitution. Also, the main point of the study was that these women were motivated to act as street prostitutes by the insecure family environment they had been exposed to since childhood. They did not have the proper protection of their parents when 
they were young. And even after marriage, they did not receive that care from their husbands. Collectivity provides care for people. Social cohesion leads to social organization. Where the individual does not receive the care that society deserves, the individual becomes distressed and troubled [20]. The main reason why women have become street prostitutes is the lack of attention, support and protection that their group deserves.

\section{References}

1. Rathnapala, Nandasena (2000). Prostitutes of Sri Lanka. Colombo; Sadeepa Publishers.

2. https://worldpopulationreview.com/country-rankings/countries-where-prostitution-is$\underline{\text { legal }}$

3. Scott, John (2014). Oxford Dictionary of Sociology. Oxford; Oxford University Press.

4. Weitzer, Ronald (2009). Sociology of Sex Work, August 2009, Annual Review of Sociology 35(1), p. 217.

5. Bozicevic Ivana, Ariyaratne Manathunge, Zoran Dominkovic, Sriyakanthi Beneragama, Kelsi Kriitmaa. (2020). Estimating the population size of female sex workers and transgender women in Sri Lanka. https://doi.org/10.1371/journal.pone.0227689, Published: January 15, 2020, https://doi.org/10.1371/journal.pone.0227689.

7 Tambiah, S.J. (2011). Polyandry in Ceylon, with Special Reference to the laggala Region. Colombo: Social Scientists Association

8 Ralf, P. (1964). Sinhalese Social Organization. Saman Publishers

9 Basnayaka, Sriyani (1988). Sri Lanka Youth, A study of reproductive Health Awareness. Colombo; Family planning association of Sri Lanka

10 Subasinghe, Wasantha. (2000). A sociological study on Virginity. Kadawatha; Author publication.

11 Obesekara, Gananath (1984). The Cult of the Goddess Pattini.The University of Chicago Press.

12 Yalman, Nur (1967). Under the Botree, University of California press

13 Hewage, Jinadasa. (Edi). (2012). Sambhasha; Pansil for social control by Ubesekara, D.M., Piriwen Education; Ministry of Education

14 Devis, Kingsly (1937). The Sociology of Prostitution. American Sociological Review, Vol. 2, No. 5 (Oct., 1937), pp. $744-755$ (12 pages), Published By: American Sociological Association

15 Collins, Randall. (1971). A Conflict Theory of Sexual Stratification. Social Problems Vol. 19, No. 1 (Summer, 1971), pp. 3-21 (19 pages), Published By: Oxford University Press. https://www.jstor.org/stable/799936

16 Wanninayake, Shantha (2017). Making A 'Home'; Internal Displacements and resettlement Processess in Sri Lanka 2002-2006.University of Gothenburg; School of Global Studies

17 Dissanayake KGC, Liyanage RP. (2020). Prostitution and Systemic Health. International Journal of Multidisciplinary Research and Development. 7(12). 
18 Liyanage RP, Hettige SS. (2019). Management of Sutika Unmada Through an Indigenous Treatment Modality. World Journal of Pharmacy and Pharmaceutical Sciences. 8(11): 157163.

19 Liyanage RP, Hettige SS, Ranasinghe RHS. (2019). Management of Othello Syndrome Through an Indigenous Treatment Modality; A Case Study. World Journal of Pharmacy and Pharmaceutical Sciences. 8(12): 188-195.

20 Spaulding, A.J. \& Simpson, G. (Trans). (1951). Emile Durkheim; Suicide; A study in Sociology. China Social Sciences Publishing House, Chengcheng Books Ltd. 